\title{
For humanistic management and against economics
}

\begin{abstract}
The paper critiques the relationship between personalist ethics and institutional economics, and accepts that institutional economics can be difficult to reconcile with humanistic management that builds on personalist ethics. Even so the paper connects impersonalist ethics with institutional economics. On this ground, the paper demonstrates how theory and practice of personalist humanist management can lean on impersonalist ethics, i.e. institutional economics. Three pathways are laid out for such leanings. It is argued that to understand these alignments is important to improve the success of humanistic management, when a market economy context is given. The paper further contends that personalist humanistic management may imply abandoning the market economy when it positions itself in opposition to institutional economic reasoning that underpins the market economy.
\end{abstract}

\section{Keywords}

Personalist humanistic management; impersonalist ethics; institutional economics; market economy; mutual gains; systemic ethics; ethical capital; homo economicus. 


\section{For humanistic management and against economics}

Being 'against' both means 'in opposition' and 'leaning on'. I can't, and I don't want to, make ethics or business ethics disappear, but I want to be clearer about what I'm leaning on.

(Parker, 1998, p. 295)

\section{Introduction}

Criticism that economics, which sees itself rooted in the tradition of Smith's Wealth of Nations, is inhumane and unethical is not a rarity throughout history. In business research such arguments regularly flared up over the past decade or so around the concept of humanistic management. The paper critically positions this debate: Is it a foregone conclusion that humanistic management inevitably finds itself in opposition to economics, or can it be 'against' economics in the sense of 'leaning on' economics? Here, the paper aims to critique the relationship between economics and humanistic management. It takes on the same research questions and makes the same contributions as humanistic management, namely 'How can the common good of the firm serve as a guide for ... management? ... and to show that different pathways of implementing the common good are inherently plausible' (Frémeaux and Michelson 2016, p. 2; similarly, Beabout 2013, p. 111). It becomes apparent that the paper is not opposed to either theory or practice of 
humanistic management but instead sets out how institutional economics and humanistic management can be selectively reconciled.

For making its case, the paper differentiates personalist humanistic management from impersonalist ethics (Section 2 follows up). On this basis, the paper aligns institutional economics with impersonalist ethics, connecting to the works of Buchanan, North, Ostrom or Williamson, to name but a few. This tradition is clearly evident already in Smith's Wealth

of Nations (Viner, 1927; Buchanan, 1976; Reisman, 1998, 2015; Wagner-Tsukamoto, 2013b). The argument is that an understanding of institutional economics as impersonalist ethics conceptually grounds personalist humanistic management and improves the practical success of personalist humanistic management - when a market economy context is given. In this way, the paper contributes to debate on business and society by spelling out how personalist humanistic management can lean on economics.

In turn, Section 2 outlines concepts of personalist humanistic management. Section 3 discusses three pathways for an impersonalist ethical reading of institutional economics and in what ways these support both theory and practice of personalist humanistic management. Section 4 discusses debate on personalist humanistic management that aims to overcome the market economy. Finally, I offer my conclusions.

\section{Personalist humanistic management: definitions and key features}


Over the past ten years or so an ever-expanding body of research on humanistic management has emerged, e.g. Melé (2003, 2009a, 2009b, 2009c), Rosanas (2008), Davila Gomez and Crowther (2009), Pirson and Turnbull (2011), Spitzeck (2011), Acevedo (2012), Sandelands (2015), or Fremeaux and Michelson (2016). There is no single ethical doctrine in which debate on humanistic management is rooted. It ranges from virtue ethics (Melé, 2003, p. 79, 2009c; Rocha and Miles, 2009, p. 445-446; Acevedo, 2012, p. 199; Beabout, 2013; Frémeaux and Michelson, 2016), stoic ethics (Opdebeeck and Habisch, 2011, p. 783), duty ethics (Kimakowitz, et al., 2011, p. 11-12), unconditional concepts of human dignity (Spitzeck, 2011, p. 51; Kimakowitz et al., 2011, p. 4-6; similarly Acevedo, 2012, p. 204, 207), Chinese values (Bettingnies et al., 2011; Ip, 2011; Opdebeeck and Habisch, 2011; Vermander, 2011), Thomistic religious thought (Rocha and Miles, 2009, p. 445-446; Wishloff, 2009; similarly Acevedo, 2012, p. 205; also Donohue-White et al., 2002, p. 1-2), to Catholicism (Grassl and Habisch, 2011, p. 45, 47; Sandelands, 2015; Frémeaux and Michelson, 2016), for instance. Humanistic management has even been associated with critical Marxist theory and communism's longstanding search for the new, good human being (e.g. Wary-Bliss and Parker, 1998; Parker, 1998; Parker et al., 2007).

In historical perspective, the human relations school (e.g. Mayo, 1933; Barnard, 1938; McGregor, 1960; Knowles and Saxberg, 1967) could be seen to selectively anticipate humanistic management. This tradition discussed ideas that are central to contemporary approaches of humanistic management. Going further back, Taylor's well-developed ideas on the 'hearty manager', who engages in the 'great, complete mental revolution' (Taylor, 1912, p. 26-27; see also Taylor, 1903, p. 63-68, 129-132; 1911, p. 27-29), can be projected to humanistic management (Wagner-Tsukamoto, 2003, p. 85-89; 2007b; 2008a); as can 
Simon's (1945, p. 52-9, 113-118) concept of the virtuous manager. In these regards, an important question for more recent theory on humanistic management is how it sees itself connecting to these earlier traditions.

Considering the variety of older and newer concepts that exist on humanistic management, it can be asked whether some shared features could capture what humanistic management essentially is. At the level of the various ethical doctrines themselves, this is likely to be a challenging interdisciplinary project. For instance, Vermander (2011, p. 705) reveals that within different humanistic traditions of Chinese values humanistic management is already set out in competing terms: That 'conflicts in substance' and difficulties to 'extract their quintessence' prevail. If common features cannot be identified, different approaches to humanistic management may find that rather than supporting each other they could be competing against each other. Should warnings of 'paradigm soup' apply, as raised by Buchanan and Bryman (2009, p. 4) for interdisciplinary management studies? The current paper tackles this problem of interrelating diverse approaches to humanistic management by connecting them to personalist ethics (or 'personalism'); and on this ground, shared features are subsequently identified for different approaches to humanistic management. The guiding maxim that is picked up is '... that a true humanistic management is personalistic', as Acevedo (2012, p. 197-198) argues with specific reference to management ethics (similarly, Donohue-White et al., 2002; Santelli et al., 2002).

Personalist ethics focuses on the wholeness of the individual person, of human character and of human nature. Yandell (1998, p. 315) defines personalism as 
... the thesis that only persons (self-conscious agents) and their states and characteristics exist, and that reality consists of a society of interacting persons.... Personalists are usually idealists in metaphysics and construct their theories of knowledge by inference from the data of self-awareness. They tend to be nonutilitarian in ethics and to place ultimate value in the person as a free, selfconscious, moral agent, rather than in either mental states or in apersonal states of affairs.

Or, as Williams and Bengtsson (2016) put this: 'Personalism always underscores the centrality of the person as the primary locus of investigation for philosophical, theological, and humanistic studies' (also Bertocci, 1986, pp. 57-58, 79; Donohue-White et al., 2002, p. 70). The approach is idealistic, as personalist ethics acknowledges (Deats, 1986, pp. 284285; Bengtsson, 2006; Williams and Bengtsson, 2016).

Bengtsson's (2006) historic tracing of personalist ethics is intriguing since it develops a conceptual umbrella that re-connects a wide range of moral philosophical and theological studies to personalist ethics, ranging from Aristotle, St. Augustine, St. Francis, Kant to Hegel and others (also Muelder, 1986; Beabout et al., 2002; Donohue-White et al., 2002; Santelli et al., 2002; Beabout, 2013; see also above, when diverse ethical roots of humanistic management were reviewed). Exemplary are Williams and Bengtsson (2016) when projecting personalist ethics to duty ethics and religious ethics: 'His [Kant's] celebrated practical categorical imperative - "Act so as to treat humanity, whether in your own person or in that of another, always as an end and never as a means only" - was incorporated nearly verbatim into Karol Wojtyła's [the Catholic Church's Pope John Paul II] “personalist 
principle"' (also, Lavely, 1986; Beabout et al., 2002, pp. 37-73; Clark, 2002). I then specify for the purposes of this paper, personalist humanistic management with a view to five shared features: (1) that describe the human agent individualistically, (2) as the whole person; (3) agree with the intentionality of individual behavior and its consequences; (4) link the achievement of common good and the good society to the goodness of individual behavior; (5) and research human nature in an ends-oriented manner. Consequently, practical intervention, as favored by personalist humanistic management, aims at moral pedagogy that promotes ethics with a view to the individual and fosters ethical motivations, intentions, attitudes and ethical character education of the individual person, as manager, employee, stakeholder, etc. (also Melé, 2003, 2009a, 2009b, 2009c; Rosanas, 2008; Rocha and Miles, 2009; Bettingnies et al., 2011; Grassl and Habisch, 2011; Ip, 2011; Kimakowitz et al. 2011; Opdebeeck and Habisch, 2011; Pirson and Turnbull, 2011; Spitzeck, 2011; Vermander, 2011; Acevedo, 2012, p. 206; Sandelands, 2015, pp. 172; Naughton, 2015, p. 180; Frémeaux and Michelson, 2016).

The idea of ends-orientation of personalist humanistic management is in opposition to a means-oriented approach, as utilitarianism and social contract economics for example tolerate this when assessing ethical outcomes of human behavior but personalist ethics rejects this. In this respect, both personalism and personalist humanistic management have been dismissive of utilitarianism: 'Philosophy, taken in itself, is above utility' (Acevedo, 2012, p. 216; also, Beabout et al., 2002, p. 110-111; Donohue-White et al., 2002, p. 73; Grassl and Habisch, 2011, p. 39). Utilitarian philosophers like Bentham or Mill (e.g. Mill, 1950, p. 16; Bentham, 1988; see also Raico, 1964, p. 32) may disagree that utilitarianism is not moral philosophy but I am confident they would concede that it portrays a different 
kind of ethics as compared to personalist ones. From the outset, the current paper argues for and accepts tolerance and understanding regarding what ethics should be about.

What does a thorough understanding of personalist humanistic management, incorporating the five shared features identified above, imply for management in a market economy when competition is rife; economic survival is a prerequisite for business; and where the ideal of common good and the good society may be approached differently than by theoretically and practically focusing on individual goodness and the portrayal of complete persons. I discuss in the next section how institutional economics can be viewed as impersonalist ethics and how this reading supports theory and practice of personalist humanistic management, especially so when a market economy context is acknowledged. The proposed synthesis starts with Smith's economics. A different synthesis of economics and ethics emerges other than one suggested by personalist humanistic management, which focuses on the centrality of the individual person. From the outset, this differs from Bengtsson (2006, p. 28) who only singled out 'pantheism' as impersonalist ethics and as an opposite to personalism (also Muelder, 1986, p. 52; Bengtsson, 2006, pp. 282-283). This then will be one of the main tasks of the paper, outlining alternative impersonalist ethics that follow Smith's economic program and its contemporary offspring. The argument is that this provides for conceptual leanings against which personalist humanistic management can grow. The thesis is that this debate is the more relevant when a market economy context is given. 


\section{Impersonalist ethics and institutional economics: personalist humanistic}

\section{management leaning on economics to achieve the common good}

Economics conventionally analyzes the exchange of goods and services among agents and how exchange is organized in society. The idea of exchange is widely interpreted, including the exchange of physical capital ('goods'); services; brand capital; knowledge, intellectual capital; human capital; time as capital; ethics and rights as capital; etc. Institutional economics then analyzes exchange in relation to different organizational setups of economic structures (private contract; organization structures of the firm; societal governance through legal and constitutional systems; international institutional structures, like regimes for trade tariffs; and so on). The goal is to find out how outcomes of capital exchange can be steered by intervening with economic institutions. This approach is impersonalist, abstracting from real people and from human nature in any complete ('ontologically correct') sense (This is followed up below when the homo economicus is discussed). Personalist features like the goodness of the individual, the whole person, intentionality and ends-orientation scarcely feature when setting out this ethics. Rather, economics focuses on outcomes of systemic intervention and in what way systems generate outcomes of capital exchange for agents and for society. From this vantage point, the moral stance and empirical 'validity' of economics are assessed - with a view to (1) desirable outcomes for interacting agents and society, (2) economic institutions and (3) capital exchange. These three pathways organize institutional economics as impersonalist ethics and they support theory and practice of personalist humanistic management. 
Pathway one to common good: Personalist humanistic management leaning on economics' mutual gains program

It may be open to inquiry that only personalist humanistic management overcame 'traditional boundaries ... [regarding the] division between a realm of "value-free" economic analysis and an area of "ethical preferences" ...' and '...dichotomies between the domains of economics (or business) and morality' (Grassl and Habisch, 2011, p. 45-46; similarly, Beabout et al., 2002, p. 109; Santelli et al., 2002, p. 44; Frémeaux and Michelson, 2016). Does economics emphasize only 'profit-making', 'self-interested individualism', 'human singularities over human commonalities' (Acevedo, 2012, p. 200-201; similarly, Wishloff, 2009, p. 150) and 'reciprocal egoism' (Melé, 2009b; Acevedo, 2012, p. 201)? Rather than doubting an ethics orientation of economics, it can be debated whether economics draws on a different concept of ethics: One that relies not on individual goodness, complete persons, intentionality, etc. instead promoting common good through a mutual gains program, both at the interaction level when agents trade capital and in societal perspective (for recent reviews, see Luetge, 2005; Wagner-Tsukamoto, 2005, 2008b; Homann, 2014; Luetge et al., 2016).

Smith's and Mandeville's programs were already normative and ethical in this respect, focused on the 'wealth of nations' or 'private vice, public good' (i.e. societal wealth; economic growth, etc.). They were explicit regarding a mutual gains program of economics: 
'A revolution of the greatest importance to the public happiness, was in this manner brought about by two different orders of people, who had not the least intention to serve the public.' (Smith, 1776/1976, p. 418) In this understanding, economics analyzes and promotes common good in the face of competitive processes, although the original intent was merely grounded in self-interested choice. Goodpaster and Matthews (1982, p. 136) recognize such unintended ethical outcomes of the market economy as 'independent' ones speaking of 'systemic morality' of the invisible hand in a market economy; Vogel (1991, pp. $108,114)$ speaks of the 'socially useful function' of the market; or, Gerde et al. (2007, p. 14) talk of 'individual gain' leading to 'benefits dispersed throughout society'. In this reading, even merely self-interested behavior can yield ethical outcomes for society, albeit as unintentional side-effects that require no altruistic 'personal goodness' from the individual. Any inadequate mutual gains outcomes are examined in this way not as a matter of too much self-interested behavior or lacking individual goodness of agents but as a matter of problems in the institutional economic governance of capital exchange. Problems are traced to governance structures that fail to properly align even merely self-interested behavior of agents for mutual gains outcomes. If problems are found, intervention with economic institutions is proposed (I discuss this systemic perspective on economic ordering in more detail below).

In societal perspective, examples of mutual gains achievements of the market economy reflect growth and rising living standards in society over time (i.e. the overcoming of poverty), the provision of employment, tax contributions of firms to the state, the innovation of high-quality products and services and so on. This sets out an economic reading of how human welfare and common good are to improve over time. At the more 
abstract end, ethical ideals of freedom and fairness shine through in this program. The studies of Hayek (1960), North and Thomas (1973), Buchanan (1975, 1987a, 1987b, 1991), Williamson $(1975,1985)$, Ostrom $(1986,1990)$, North and Weingast (1989) or North (1990) reflect this argument. Ethics has never in this respect separated from economics, as implied by personalist humanistic management (e.g. Beabout et al., 2002, p. 110; Wishloff, 2009, p. 138, 149-150; Naughton, 2015; Sandelands, 2015; also, Santelli et al., 2002; Donohue-White et al., 2002). Rather, it was a new brand of ethics that drove Smith when pioneering the economic approach. Indeed, Smith broke in this regard with his earlier approach to ethics, his Theory of Moral Sentiments. This theory was grounded in sympathy-based virtue ethics and aligns with personalist ethics and personalist humanistic management (Smith, 1759/1966; see also Figure 1 below; Wagner-Tsukamoto, 2013b).

Economics' vision of mutual gains has ethical implications for personalist humanistic management. Once economic governance for mutual gains outcomes is established, personalist humanistic management can grow because the basic foundations for management intervention are aligned with economic thinking (and the ethics program that economics reflects). In this sense, the mutual gains program of economics sets ethical boundaries and creates space within which personalist humanistic management can establish itself. Personalist humanistic management would then not develop in any moral vacuum but is aligned with the mutual gains ethics of economics and how this ethics makes concessions to competition and survival requirements on the firm in a market economy context.

Earlier traditions in personalistic humanistic management were quite outspoken that such partnerships with economics should be sought. Connecting to the human relations 
school, Swart (1973, p. 42, 50), for instance, explicitly justified practices in personalist humanistic management in relation to profitability or productivity. This moves towards the economizing of personalist humanistic management, linking to instrumental stakeholder management ethics or economized versions of CSR management. It also mirrors more direct alignment with a mutual gains program at the interaction level, when the firm and its stakeholders exchange capital. In a rather similar economizing frame of mind are some of the more recent publications on humanistic management that examine competitive behavior of the firm, e.g. Offstein and Gnyawali (2006). They openly connected humanistic management to strategic human resource management to improve the competitiveness of the firm (See also Lepak and Snell, 1999). In this respect, at least some researchers on personalist humanistic management do not seem to decline, at least not explicitly, economic ideas like profitability, branding, efficiency, productivity, etc. My argument is that such economic criteria need to be considered at a foundational level of personalist humanistic management with respect to economics' mutual gains approach to ethics.

Pathway two to common good: Personalist humanistic management leaning on institutional economic governance and system

Institutional economics favors economic organization for systemically promoting ethical standards. This is more visible in developed market economies, when capital exchange, both inside and outside the firm, is to a significant degree institutionally enacted 
by organizational, legal, quasi-legal, constitutional structures and so on (Buchanan, 1975, 1987a, 1987b, 1991; Williamson, 1975, 1985; Vanberg, 1992, 1994, 2001; Homann, 1997, 2014; Wagner-Tsukamoto, 2003, 2005, 2007a, 2008b; Luetge 2005; Heyne 2008; Boettke, 2014; Congleton, 2014; Luetge et al. 2016). The 'economic market' and the 'legal state' closely interrelated in this program, as this has been doubted at times by personalist humanistic management (e.g. Naughton, 2015, p. 184). Already Smith (1776/1976, Books IV and $\mathrm{V}$ ) was outspoken regarding a strong institutional dimension of business activity in a market economy (Viner, 1927; Reisman, 1998; Wagner-Tsukamoto, 2012, 2013b).

Characterizations of Smith, as put forward by personalist humanistic management, as a 'liberal' who unrestrainedly held up laissez-faire markets (e.g. Grassl and Habisch, 2011, p. 41; similarly, Donohue-White et al., 2002, p. 56; Wishloff, 2009, p. 149), can be contested.

Institutional economics targets undesirable effects of self-interested choice in capital exchange processes by examining economic institutions and the kind of ordering and rulemaking that comes with them. For example, from Smith to contemporary economics, opportunism, managerialism, corruption, etc. have been analyzed in relation to economic institutions (Taylor, 1903, p. 32, 1911, p. 19-20, 1912, p. 118-119, 151, 153; Berle and Means, 1932; Buchanan, 1975, 1987a, 1987b; Williamson 1975, 1985; Vanberg, 1992, 2001; also, Luce and Raiffa, 1957; Novak, 1996, p. 141; Wagner-Tsukamoto, 2003, p. 85-89, 2008a; Homann, 2014). Already Smith (1776/1976, p. 64, 638-639, 641, 752, 819) did not trace such problems, which yielded the exploitation of agents in exchange relationships, to troubles with human nature, poor character or inadequate personal goodness. Rather, he blamed economic institutions and the lack of them. This mirrors conventional economic 
analysis which aims to prevent socially undesirable outcomes by examining system and situation:

I mean not ... by any thing which I have here said to throw any odious imputation upon the general character of the servants of the East India company, and much less upon that of any particular persons. It is the system of government, the situation in which they are placed, that I mean to censure, not the character of those who have acted in it. They acted as their situation naturally directed, and they who have clamored the loudest against them would, probably, not have acted better themselves. ... Such exclusive [monopoly] companies ... are destructive to those which have the misfortune to fall under their government. (Smith, 1776/1976, p. 641, emphasis added)

Smith aimed to prevent socially undesirable outcomes that could result from self-interested behavior. Like modern institutional economists, he scrutinized incentive effects of 'situation' and 'system' - but not explicitly as 'person' or 'character'. The model of self-interest (the 'homo economicus') is instrumentally useful and needed in this regard, as a 'tool' or method of analysis (as discussed in more detail below). Indeed, if the idea of self-interest were given up, economic institutions could no longer be examined for detrimental effects of selfinterested choice and then it may be all the more difficult to protect the good person from exploitation by other agents, who generally act solely on grounds of self-interest. 
Complaints about 'corruption', 'weak laws and lax enforcement [of laws]', or 'lack of a free press' (Ip, 2011, p. 691) would alert institutional economists to improve the institutional economic framework of governance which ethically constrains business behavior in a market economy. A critical question is how a personalist humanistic manager on his/her own, as referred to by Ip (2011, 691-692), could survive in an institutional-legal and constitutional context where deficits at a systemic level economically penalize the good person. Most revealing here are the troubling experiences of deeply religious and apparently personalist managers and the apparent lack of economic success they met (Child, 1964; Cheung and King, 2004; Wagner-Tsukamoto, 2008b).

What are the implications for personalist humanist management which tried to solve comparable problems, as raised by Smith (1776/1976, p. 641), but independent of economic governance and independent of economic analysis? Could personalist humanistic management remedy institutional deficits, particularly if personalist humanistic management generated greater costs than gains to those who practice it? In my view, personalist humanistic management here needs to lean on systemic insights from economic analysis, as Smith so centrally captured them for the East India Company. The argument is that through intervention with economic institutions interactions over capital exchange can be steered away from undesirable effects of self-interest, managerialism, opportunism, free rider problems, and so on. Once institutional economic structures have been created in this way, organization members and stakeholders can more readily follow personalist humanistic principles because an existing systemic framework protects them against exploitation, opportunism, corruption, immorality etc. at least up to a certain level (i.e. the ethical standards that have been laid down in institutional structures). Some of Santelli et 
al.'s $(2002$, p. pp. $112-113,121)$ comments move in this direction when stressing that market economies should integrate personalist ethical principles into their institutional frameworks. The current paper follows this up through institutional economic argument, and how such argument has permeated economic thinking since Smith's studies of economics. Personalist humanistic management can then systemically lean on economics.

In globalizing economic contexts, constitutional and legal-institutional economic ordering needs to be increasingly negotiated through universal frameworks, through the UN, WTO, OECD, and other international trade and political bodies. Such institutional economic governance of global markets is not uncomplicated, especially so when competition transcends national markets. Yet, advances have been made (Vanberg, 1992, 2001; Arevalo et al., 2013; see also Wagner-Tsukamoto, 2005, 2007a, 2008b).

Pathway three to common good: Personalist humanistic management leaning on ethical capital creation

Pathways one and two imply that ethics is not negotiated amongst agents themselves (the firm and its stakeholders). This reflects Smith's classic understanding that markets as such are moral-free zones: Ethics then only appears as economics' mutual gains program, which reflects the larger ethical legitimization of the market economy, and ethics is systemically laid down in institutional frameworks that constrain markets. Pathway three 
sets out a different economic route, with ethics being directly negotiated amongst the agents who exchange capital. This sets out a competing understanding as to how personalist humanistic management can lean on economics and how it can become operational in markets. The idea of ethical capital is central here. Ethical capital can be generated both as transaction capital and as production capital.

In the transaction capital perspective, humanistic concepts - integrity, honesty, goodness, trust, for instance (e.g. Rocha and Miles, 2009, p. 454; Parra Guillén et al., 2011, p. 607-612; Opdebeeck and Habisch, 2011, p. 783-784; further literature was quoted above) - are reconstructed in economic terms as transaction capital. Such capital stabilizes exchange processes and in this way, facilitates them. Then, categories like trust or goodness enter an economic gains-loss assessment of profitability, productivity, efficiency, competitiveness, etc. (e.g. Anderson and Tollison, 1992).

Assessed from a production capital perspective, a firm can adopt the strategy of producing products or services which exceed the minimum moral standards required by constitutional and institutional economic structures; e.g. regarding what is permissible in terms of environmental pollution laws, or what is legally expected regarding engagement in fair trade partnerships with suppliers; or what is legally required, if anything, regarding philanthropic contributions to the local community, and so on (Wagner-Tsukamoto, 2005, 2007a, 2008b, 2013a). Examples of such ethical capital are products and services that promote environmentally-friendly, fair trade, organic, animal-friendly issues. Such business behavior has ethical outcomes for society, common good being fostered. Utilizing this approach, management ethics is economized, instrumentalized and 'commodified'. It is projected to considerations of market share, branding, profitability, competitiveness, etc. 
Importantly, the consumer (stakeholders in general) being the person who decides which products or services to purchase and how to choose them is not instrumentalized. In these latter regards, personalist humanistic management can focus on the stakeholder as the person; for example, when promoting ethical stakeholder education; and the firm too can support such ethical stakeholder education for improving the trade of ethical capital.

At times researchers on personalist humanistic management hint at an economizing approach to business ethics when they talk about the 'legitimization' of profit-generating management (e.g. Kimakowitz et al., 2011, p. 8-9); and economic goals of the firm like 'profitability', 'efficiency' or 'productivity' (e.g. Melé, 2003, p. 85, 2009a, p. 413; Rosanas, 2008, p. 460; Grassl and Habisch, 2011, p. 44, 47). Nevertheless, how reconciliation is to be undertaken is left open, especially so regarding whether, and if so how, the economizing of personalist humanistic management through ethical capital generation should be approached. If personalist humanistic management is not aligned with ethical capital creation, then managers may suffer conflicts of conscience and the economic viability of personalist humanistic management may just be accidental or forsaken (Child, 1964; Cheung and King, 2004; Wagner-Tsukamoto, 2008b).

The role of the model of self-interest (homo economicus) in developing economic pathways that support personalist humanistic management 
Bengtsson (2006, pp. 282-283), like many contemporary personalist humanist management, is worried about research that does not take account of whole persons:

The most obvious achievement of personalism ... may well be its demonstration that philosophy which does not properly consider the reality of the person, however elusive and difficult it may be, ultimately yields strange and unacceptable results. ... The modern project ... [which focused on] new impersonal wholes failed convincingly to assert objectivity. In this situation, the early personalists addressed the decisive and pressing question of the possibility of reconciling moral and axiological normativity and theistic metaphysics with the deepened understanding of individuality.

Importantly, Bengtsson's target of criticism is philosophy, i.e. impersonalist ethics in the version of pantheism (also Bertocci, 1986, p. 55). In contrast, personalist humanistic management argues (like Bengtsson) for the philosophical project of portraying complete human nature, as homo sapiens or zoon politicon (Melé, 2003, 2009a, 2009b, 2009c; Rosanas, 2008, p. 448, 450, 455; Rocha and Miles, 2009, p. 447; Wishloff, 2009, p. 149; 151152; Pirson and Turnbull, 2011, p. 102-104; Frémeaux and Michelson 2016; see also Donohue-White et al., 2002, p. 77; Goshal et al., 1999; Goshal, 2005, p. 81). However, differing from Bengtsson, personalist humanistic management finds another target: It shifts critique against science and laments the homo economicus as 'economicist fallacy' or 'reductionist economism'; and perceives economics as value-free science that lacked ethical 
groundings (Grassl and Habisch, 2011, pp. 40, 42; Acevedo, 2012, pp. 200, 203, 208; Pirson et al., 2011, p. 316-318; Frémeaux and Michelson, 2016). Research on the 'personalist economy' argues similarly (Beabout et al., 2002, p. 111; Santelli et al., 2002, p. 44; DonohueWhite et al., 2002, pp. 93-96, 103); as does behavioral economics (early on, Simon, 1955, 1956, 1993; Sen, 1990), or economic sociology (e.g. Etzioni, 1988). Or, to pick up comparable criticism from the $19^{\text {th }}$ century which suggested that Smith aimed to '... transform political economy into a mere natural history of egoism' (Hildebrand, 1848, p. 275; see also Gide and Rist, 1915, p. 394).

These research traditions agree that the economic analysis of human behavior must, as with the analysis of human behavior in the field of philosophy, move 'Beyond Selfinterest' (Mansbridge 1990; Beabout et al. 2002), 'minimize self-interest' (Opdebeeck and Habisch, 2011, p. 779) and dismiss 'profit-making of the firm' (Frémeaux and Michelson 2016, pp. 1-2). A critical question is whether these shifts from philosophical inquiry to scientific ones are recognized by those who argue for them, with all the methodical and conceptual implications they may have regarding research approach and the portrayal of human nature. An important question here is how to ground management ethics research, in our case, research on personalist humanistic management; either in philosophy or in science and how to negotiate shifts regarding the complete portrayal of human nature versus the modeling of human nature when moving from philosophical inquiry to scientific ones.

Smith's economics radically altered method and theory used by philosophies and ethics traditions that portray complete persons or promote individual goodness and which mirror personalist humanistic management. The beauty of the economic approach is, as 
Smith or Mandeville realized, that socially desirable outcomes can be generated for both the trading agents and society, through intervention with economic institutions. This is feasible even when agents only look after their self-interests because, conceptually, economics does not substitute in its analysis the idea of self-interest through personalist humanistic notions of integrity, belief, trust, individual goodness, and so on.

I then interpret the homo economicus as a mere method: As a calculus of rational, self-interested, optimizing choice, being little more than a tool or pre-empirical, heuristic idea. It methodically organizes economic research and it is instrumental for developing the above pathways and how to read these with a view to ethics. Therefore, in economic analysis the homo economicus is neither empirically testable nor morally rateable as an image of human nature. It cannot be compared against the whole person, individual goodness and true human nature (already stressed by Smith, 1776/1976, p. 25; or later, by Buchanan, 1975, 1987a, 1987b; Becker, 1976, 1993; Machlup, 1978; Pies, 1993; Homann, 1994, 1997, 2014; Suchanek, 1994; Wagner-Tsukamoto, 2003, 2009, 2010; Luetge 2005; Heyne, 2008; Luetge et al. 2016). The whole person and individual goodness, which is the central focus of personalist humanistic management, conventionally disappear in economic analysis, being shortened to the homo economicus. Nevertheless, in the way that the unrealistic crash dummy is still useful for car design purposes, so the artificial construct homo economicus works for designing economic institutions that organize capital exchange for mutual gains outcomes. The vast economic literature on industrial organization, public finance, economic development and so on similarly draws on the homo economicus to examine the role of institutions, such as regulations and laws, with a normative view to systemically steering socially desirable outcomes for agents and society. 
Here, economics has an optimistic and precise outlook on individualism and on the individual for the specific purposes of discussing economy and economic organization. Some branches of moral philosophy share such optimism on the individual, for example utilitarianism. Bentham clearly was not an economist but not dissimilar to economists, he analyzed the individual's (self-)interests and was skeptical of community and communitarian ideals for organizing society. As he put this: 'It is vain to talk of the interests of the community, without understanding what is the interest of the individual' (Bentham, 1988, p. 3). Economics turns this idea of utilitarianism methodically, building its approach to social and ethical analysis on the model of the homo economicus.

Dahrendorf (1973) or Blau (1976, p. 5) similarly pointed at this issue for homo sociologicus, which in their understanding is another unrealistic heuristic fiction utilized for social analysis, being extremely useful for methodically organizing sociological research on how people perform roles in society. Popper poignantly summarized that 'The "zero method" [e.g. the homo economicus, homo sociologicus, etc.] of constructing rational models is not a psychological but rather a logical method.' (Popper, 1994, p. 158, emphasis as in original; also, Homann, 1994; Suchanek, 1994; Wagner-Tsukamoto, 2013b) With their unique tools in hand, sciences like psychology, anthropology, or sociology explain economy, ethics and society differently from economics by employing different models of human nature, such as homo psychologicus, homo anthropologicus or homo sociologicus. Here again these are only models of human nature but not portrayals of whole persons, as Dahrendorf, Blau and Popper stressed. In this respect, an important question is how personalist humanistic management could reconnect to any of the social sciences since all 
of them only engage models of human nature, in their respectively different terms, but do not entertain complete philosophies of human nature.

Interestingly, at times researchers on personalist humanistic management followed economic lines of analyzing organizational behavior, seeming to apply the model of the homo economicus. For example, the institutional reform proposals of Pirson and Turnbull (2011, p. 109-111) for curbing homo economicus 'excesses', such as opportunistic behavior of managers, require the homo economicus as a methodic tool of analysis. Implicitly at least, Turnbull and Pirson here leaned on economics. Despite this, they still explicitly claim to oppose economics, branding the homo economicus as empirically unrealistic and aiming to replace it with the portrayal of the whole person. This same topic has captivated economics and management studies from its beginnings; early on Smith (1776/1976, p. 641, as quoted above), Taylor (1903, 1911), Berle and Means (1932) or Williamson (1967). They all analyze self-interest, opportunism, managerialism, etc. Taylor's historic studies are particularly intriguing in light of his admission that his hope for curbing managerial self-interest through the 'great mental revolution' of managerial attitudes had failed (Taylor, 1912, p. 153). I traced this failure to management intervention that compares to contemporary personalist humanist management (Wagner-Tsukamoto, 2003, pp. 85-89; 2007b; 2008a).

I do however agree completely with the diagnosis that the homo economicus is unrealistic and does not compare well to true human nature; that it is empirically false and morally incomplete as compared to homo sapiens or zoon politicon. My point therefore is, that this does not matter because institutional economics, which emerged out of Smith's economics, empirically and morally merely assess capital exchange, economic institutions and mutual gains outcomes. Indeed, the three pathways to economic ethics, as set out 
above, all build methodically on the homo economicus. Consequently, I disagree with personalist humanistic management that economics which builds on the idea of selfinterest, does not constitute ethics anymore and that only the approach of personalist humanistic management could improve ethics. The alternative is not seen: That Smith's Wealth of Nations is also ethics that aims at common good and the good society. But it is ethics with a difference, and its model of human nature essentially captures this difference.

Figure 1 sums up how the ethics programs of personalist humanistic management and economics can be positioned in relation to each other. Declining the homo economicus as tool of analysis, implies in my understanding that a conventional research program of economics was abandoned, in favor of one of the alternatives depicted by Figure 1.

=ニニ

Please insert Figure 1 about here.

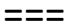




\begin{tabular}{|c|c|c|c|}
\hline & & \multicolumn{2}{|c|}{ Ethics orientation } \\
\hline & & $\begin{array}{l}\text { Common good through personalist } \\
\text { humanistic management: focus on the } \\
\text { individual person, 'individual morality' }\end{array}$ & $\begin{array}{c}\text { Common good through non-personalist } \\
\text { ethics: focus on system and social } \\
\text { structures }\end{array}$ \\
\hline \multirow{2}{*}{ 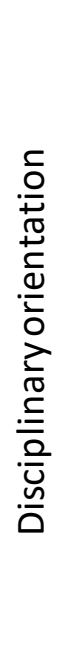 } & 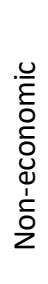 & $\begin{array}{l}\text { Non-economic, individualistic } \\
\text { ethics: Personalism in the } \\
\text { tradition of virtue ethics, } \\
\text { religious ethics; Kantianism; } \\
\text { including Smith's } 1759 \text { version } \\
\text { of sympathy-based virtue } \\
\text { ethics }\end{array}$ & $\begin{array}{l}\text { Non-economic, systemic } \\
\text { ethics: } \\
\text { Macro-sociology } \\
\text { (e.g. Blau 1976; Coleman 1990; } \\
\text { Luhmann 2008, 2012) }\end{array}$ \\
\hline & 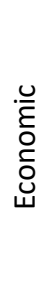 & $\begin{array}{l}\text { Economic, individualistic ethics: } \\
\text { Behavioral economics (e.g. Simon } \\
\text { 1945, 1993; Etzioni 1988; } \\
\text { Mansbridge 1990; Sen 1990); } \\
\text { personalist economics (Beabout } \\
\text { et al. 2001; Donohue-White et al. } \\
\text { 2002; Santelli et al. 2002) }\end{array}$ & $\begin{array}{l}\text { Economic, systemic ethics: } \\
\text { 'Economics as ethics' - mutual } \\
\text { gains; institutional economic } \\
\text { order; ethical capital; including } \\
\text { Smith } 1776 \text { (as discussed } \\
\text { throughout the paper) }\end{array}$ \\
\hline
\end{tabular}

Figure 1: Positioning of humanistic management

\section{Personalist humanistic management outside the market economy}

If we question, for conceptual, methodological or ethical reasons, ideas like competition, profit-making or self-interested choice, mainstream economics and the market economy system are contested. This inquiry can arise for personalist humanistic management too: Is a possibly different economic system being aimed at, rather than reforming the market economy? Acevedo (2012, p. 212) states, following similar lines of Santelli et al. (2002, p. 124), Melé (2003, p. 79), Rosanas (2008), Kimakowitz et al. (2011, p. 
4-5) or Spitzeck (2011, p. 51), that 'markets and firms exist for the sustenance and flourishing of the human person, and not conversely.' Or, Grassl and Habisch (2011, p. 45) argue for the primacy of 'authentic humanism' over economic goals such as profitability or productivity. The unconditional well-being of the whole person is argued for and this is put in opposition to 'economic rationality', the 'flourishing of markets and firms' and 'legitimized profits' (Kimakowitz et al., 2011, pp. 11-12). The question is whether an economic system can be set out and legitimized in a way that prioritizes the human person as such? Researchers on personalist humanistic management are not clear on this issue. A critical issue for personalist humanistic management is to outline in what way it aims to implement the unconditional 'flourishing of the human person', Kantian perceptions of managerial duty, minimizing self-interest, etc. inside the market economy or whether the market economy as such is contested and if so, how and why.

Exit from the market economy does not seem to be explicitly advocated by many researchers on personalist humanistic management but discarding (for example) the model of self-interest and the idea of competition and contesting profit-making may imply this. Is indeed a 'personalist humane economy' the goal, as Beabout et al. (2002, pp. 109-110), Donohue-White et al. (2002) or Santelli et al. (2002) openly developed this idea to replace the market economy system (similarly Frémeaux and Michelson 2016, p. 3). Common good is then aimed at in very different terms than in economic ones - through gift-giving, altruism, moral self-restraint and putting community first (Donohue-White, et al. 2002, pp. 71, 103; Santelli et al., 2002, pp. 75-77, 95, 114-115, 127). Specific superiority, both in ethical terms and in terms of growth, efficiency of coordination, innovation criteria within 
the economy, rising living standards over time, etc. needs to be demonstrated for such a new type of economic system.

More explicit and radical are Marxist approaches to personalist humanistic management. Community is viewed as an essential precondition for meaningful life, meaningful work and creative labor (Wray-Bliss and Parker, 1998, pp. 35, 37, 41, 48, 50-51; also, Parker, 1998). The ultimate goals are communitarian self-governance and the selfcreation of humans in a system of 'interdependence and cooperation', the idea of competition being contested (Wray-Bliss and Parker, 1998, p. 38; not dissimilarly, DonohueWhite et al., 2002, p. 71; Santelli et al., 2002, p. 114). Further utopian alternatives to the market economy are set out by Parker (2002) or Parker et al. (2007). These proposals may be uncompromising but they are conceptually precise. It is this conceptual clarity which research on personalist humanistic management may not always have demonstrated: How to implement personalist humanistic management inside or outside the market economy; and how to dismiss alternative concepts of personalist humanistic management, like Marxism? For example, Wishloff's (2009, p. 150-152) advocacy of personalist humanistic management. His critique of capital accumulation and his arguments for communitarianism do not seem to be too far removed from Marxist communist concepts, although he is not explicitly arguing for abandoning the market economy. However, following such lines of argument can inadvertently lead us to debate the economic system. Such debate about economic systems can be very fruitful for clarifying what a certain ethics approach to management is about. The question is whether personalist humanistic management wishes to enter this debate. As noted, Marxist research on personalist humanistic management clearly aims to do so. 


\section{Conclusions}

Undeniably, ethics and economics need to be reconciled. However, ethical aspiration towards common good and the good society cannot be exclusively claimed by personalist humanistic management. The paper discussed three pathways as to how personalist humanistic management can lean on impersonalist ethics that we know as economics: (1) The mutual gains program of economics; (2) the economic systemizing of traditional ethics, which may reflect principles of personalist humanistic management, in institutional economic structures that frame a market economy; and (3) the economizing of ethical expectations of personalist humanistic management in processes of capital exchange, as ethical capital. The pathways contest that '...we lack a coherent, up-to-date defense of the moral superiority of economic liberty', as personalist researchers suggest this for the market economy (Donohue-White et al., 2002, p. 85). Unless these pathways are aligned with, personalist humanistic management may accidentally or sporadically survive only in a market economy context, when competition is present, and companies need to strive for economic survival, profitability etc.

Importantly, the model of self-interest is only instrumentally useful for setting out economic pathways that align personalist humanistic management with economics. Nevertheless, the homo economicus is often targeted by personalist humanistic management as the amoral, immoral, inhumane or empirically false image of the person. 
The paper argued that the shifting of such philosophical critique against the sciences (in our case, institutional economics) is unfortunate since the homo economicus is no more than a tool of economic analysis, which methodically organizes the empirical and moral analysis of mutual gains outcomes, capital exchange and economic institutions. The main theses developed by the paper then argue that economics' vision of ethics is different, yet foundational for personalist humanistic management. When aiming to reform the market economy from within, personalist humanistic management may have to clarify how it conceptually positions itself in relation to economics and how it engages ideas that set out the market economy, like competition, economic survival, profitability, etc. If such debate is neglected, personalist humanistic management may find itself in opposition to these ideas and then the competitiveness and economic viability of the firm may suffer; and consequently, personalist humanistic management may deteriorate in economic interactions too.

However, at times, personalist humanistic management may have entered debate about economic system and exit from the market economy, but without necessarily intending to do so. From the humanistic literature I have reviewed, possibly only Marxist ethics lucidly argue why and how the market economy should be overcome by drawing on principles of personalist humanistic management and other ideas. Conceptually the approach appears clear, although I do not necessarily share its optimism that the resulting society and economy would be fairer and more humane. In this respect, personalist humanistic management may have to clearly choose its ground: How the unqualified focus on the whole person and individual goodness may imply abandoning the market economy; and how the resulting society would still be fairer and more humane, and possibly be 
different from a Marxist society. Such debate about economic systems is even more important if one concedes that a full merger of personalist humanistic management ethics with principled ideas of the market economy is difficult to achieve. The pathways discussed in this paper then only selectively reconcile personalist humanistic management with economics, because alignments were approached by taking a market economy context for granted. 


\section{References}

Acevedo, A., 2012. Personalist business ethics and humanistic management. Journal of Business Ethics 105, 197-219.

Anderson, G. M., Tollison, R. D., 1992. Morality and monopoly: The constitutional political economy of religious rules". Cato Journal 12, 373-392.

Arevalo, J. A., Aravind, D., Ayuso, S., Roca, M., 2013. The Global Compact: An analysis of the motivations of adoption in the Spanish context. Business Ethics. A European Review 22, 1-15.

Barnard, C. I., 1938. The Functions of the Chief Executive. Harvard University Press, Cambridge, Mass.

Beabout, G. R., 2013. The Character of the Manager. Palgrave Macmillan, Basingstoke.

Beabout, G. R, Crespo, R. F., Grabill, S. J., Paffenroth, K., Swan, K., 2002. Beyond Self-interest: A Personalist Approach to Human Action. Lexington, Oxford.

Becker, G. S., 1976. The Economic Approach to Human Behavior. University of Chicago Press, Chicago.

Becker, G. S., 1993. The economic way of looking at behavior. Journal of Political Economy 101, 385-409.

Bengtsson, J.O., 2006. The Worldview of Personalism. Origins and Early Development. Oxford University Press, Oxford.

Bentham, J., 1988. The Principles of Morals and Legislation. Prometheus, New York. 
Berle, A. A., Jr., Means, G., 1932. The Modern Corporation and Private Property. Macmillan, New York.

Bertocci, P. A., 1986. Borden Parker Bowne and his personalistic theistic idealism. In: Deats, P., Robb, C. (Eds.), The Boston Personalist Tradition in Philosophy, Social ethics, and Theology. Mercer University Press, Macon, 55-80.

Bettignies, H.-C., de, Ip, P. K., Bai, X., Habisch, A., Lenssen, G., 2011. Practical wisdom for management from the Chinese classical traditions. Journal of Management Development 30(7/8), 623-628.

Blau, P. M., 1976. Introduction: parallels and contrasts in structural inquiries. In: Blau, P. M. (Ed.), Approaches to the Study of Social Structure. Open Books, London, 1-20.

Boettke, P. J., 2014. What should classical liberal political economists do? Constitutional Political Economy 25, 110-124

Buchanan, J. M., 1975. The Limits of Liberty. Between Anarchy and Leviathan. University of Chicago Press, Chicago.

Buchanan, J. M., 1976. Public Goods and Natural Liberty. In: Wilson, T., Skinner, A. S. (Eds.), The Market and the State: Essays in Honour of Adam Smith. Clarendon Press, Oxford, 271-286.

Buchanan, J. M., 1987a. Economics between Predictive Science and Moral Philosophy. A \& M University Press, College Station, Texas.

Buchanan, J. M., 1987b. The constitution of economic policy. American Economic Review 77, $243-250$. 
Buchanan, J. M., 1991. The Economics and the Ethics of Constitutional Order. University of Michigan Press, Ann Arbor, MI.

Buchanan, D., Bryman, A., 2009. The organizational research context: properties and implications. In: Bryman, A., Buchanan, D. (Eds.), The Sage Handbook of Organizational Research Methods. Sage, London, 1-18.

Cheung, T. S., King, A. Y., 2004. Righteousness and profitableness: the moral choices of contemporary Confucian entrepreneurs. Journal of Business Ethics 54, 245-260.

Child, J., 1964. Quaker employers and industrial relations. Sociological Review 12(3), 293313.

Clark, M. T., 2002. The personalism of Karol Wojtyla. In: Buford T. O., Oliver, H. H. (Eds.), Personalism Revisited. Its Proponents and Critics. Rodopi, Amsterdam, 325-343.

Coleman, J. S., 1990. Foundations of Social Theory. Harvard University Press, Cambridge, Mass.

Congleton, R. D., 2014. The contractarian constitutional political economy of James Buchanan. Constitutional Political Economy 25, 39-67.

Dahrendorf, R., 1973. Homo Sociologicus. Routledge and Kegan Paul, London.

Davila Gomez, A. M., Crowther, D., 2009. Humanistic management education: richness, challenges and possibilities. In: Bubna-Litic, D. (Ed.), Spirituality and Corporate Social Responsibility Interpenetrating Worlds. Gower, Farnham, 177-197. 
Deats, P., Robb, C. (Eds.), 1986. The Boston Personalist Tradition in Philosophy, Social Ethics, and Theology. Mercer University Press, Macon.

Donohue-White, P., Grabill, S. J., Westley, C., Zúñiga, G., 2002. Human Nature and the Discipline of Economics: Personalist Anthropology and Economic Methodology. Lexington, Oxford.

Etzioni, A., 1988. The Moral Dimension: Towards a New Economics. Free Press, New York.

Frémeaux, S., Michelson, G., 2016. The common good of the firm and humanistic management: conscious capitalism and economy of communion. Journal of Business Ethics, published online DOI 10.1007/s10551-016-3118-6.

Gerde, V. W., Goldsby, M. G., Shepard, J. M., 2007. Moral cover for capitalism. The harmony-of-interest doctrine. Journal of Management History 13, 7-20.

Ghoshal, S., 2005. Bad management theories are destroying good management practice. Academy of Management Learning and Education 4(1), 75-91.

Ghoshal, S., Bartlett, C. A., Moran, P., 1999. A new manifesto for management. Sloan Management Review 40(3), 9-20.

Gide, C., Rist, C., 1915. A history of economic doctrines: from the time of the physiocrats to the present day. Reprinted in: Backhouse, R. E. (Ed.), 2000. Early Histories of Economic Thought 1824-1924, Vol. 8. Routledge, London.

Goodpaster, K. E., Matthews J. B., 1982. Can a corporation have a conscience? Harvard Business Review 60(1) (January-February), 132-141. 
Grassl, W., Habisch, A., 2011. Ethics and economics: towards a new synthesis for business. Journal of Business Ethics 99, 37-49.

Hardin, G., 1968. The tragedy of the commons. Science 162, 1243-1248.

Hayek, F. A., 1960. The Constitution of Liberty. Routledge \& Kegan Paul, London.

Heyne, P., 2008. 'Are Economists Basically Immoral?' and Other Essays on Economics, Ethics, and Religion. Ed. by Brennan H.G. and Waterman, A. M. C., Liberty Fund, Indianapolis.

Hildebrand, B., 1848. Die Nationalökonomie der Gegenwart und Zukunft. J. Ruetten, Frankfurt.

Homann, K., 1994. Homo oeconomicus und Dilemmastrukturen. In: Sautter, H. (Ed.), Wirtschaftspolitik in offenen Volkswirtschaften, Vandenhoeck und Ruprecht, Göttingen, 387-411.

Homann, K., 1997. Sinn und Grenze der ökonomischen Methode in der Wirtschaftsethik. Volkswirtschaftliche Schriften 478, 1-42.

Homann, K., 2014. Sollen und Können. Grenzen und Bedingungen der Individualmoral. European University Press, Vienna.

Ip, K., 2011. Practical wisdom of Confucian ethical leadership: a critical inquiry. Journal of Management Development 30(7/8), 685-696.

Kimakowitz, E. v., Pirson, M., Dierksmeier, C., Spitzeck, H., Amann, W., 2011. Introducing this book and humanistic management. In: Kimakowitz, E. v., Pirson, M., Dierksmeier, 
C., Spitzeck, H., Amann, W. (Eds.), Humanistic Management in Practice. Palgrave Macmillan, Basingstoke, 1-12.

Knowles, H. P., Saxberg, B. O., 1967. Human relations and the nature of man. Harvard Business Review 45(2), 22-40 and 172-176.

Lavely, J. H., 1986. Personalism's debt to Kant. In: Deats, P., Robb, C. (Eds.), The Boston Personalist Tradition in Philosophy, Social Ethics, and Theology. Mercer University Press, Macon, 23-37.

Lepak, D. P., Snell, S. A., 1999. The human resource architecture: toward a theory of human capital allocation and development. Academy of Management Review 24, 538556.

Luce R. D., Raiffa, H., 1957. Games and Decisions: Introduction and Critical Survey. J. Wiley, New York.

Luetge, C., 2005. Economic ethics, business ethics and the idea of mutual advantages. Business Ethics. A European Review 14, 108-118.

Luetge, C., Armbrüster, T., Müller, J., 2016. Order ethics: bridging the gap between contractarianism and business ethics. Journal of Business Ethics 136, 687-697.

Luhmann, N., 2008. Die Moral der Gesellschaft. Suhrkamp, Frankfurt.

Luhmann, N., 2012. Theory of Society. Stanford University Press, Stanford.

Machlup, F., 1978. Methodology of Economics and Other Social Sciences. Academic Press, New York. 
Mansbridge, J. J. (Ed.), 1990. Beyond Self-Interest. University of Chicago Press, Chicago.

Mayo, E., 1933. The Human Problems of an Industrial Civilization. Macmillan, New York.

McGregor, D., 1960. The Human Side of Enterprise. McGraw-Hill, New York.

Melé, D., 2003. The challenge of humanistic management. Journal of Business Ethics 44, 77-

88.

Melé, D., 2009a. Editorial introduction: towards a more humanistic management. Journal of Business Ethics 88, 413-416.

Melé, D., 2009b. Current trends in humanism and management. In: Spitzeck, H., Pirson, M., Amann, W., Khan, S., Kimakowitz, E. v. (Eds.), Humanism in Business. Cambridge University Press, Cambridge, 123-139.

Melé, D., 2009c. Integrating personalism into virtue-based business ethics: the personalist and the common good principles. Journal of Business Ethics 88, 227-244.

Mill, J. S., 1950. Utilitarianism. On Liberty and Representative Government. Dutton, New York.

Muelder, W. G., 1986. Personalism's debt to Hegel. In: Deats, P., Robb, C. (Eds.), The Boston Personalist Tradition in Philosophy, Social Ethics and Theology. Mercer University Press, Macon, 39-54.

Naughton, M., 2015. Thinking institutionally about business: seeing its nature as a community of persons and its purpose as the common good. In: Melé, D., Schlag, M. (Eds.), Humanism in Economics and Business. Springer, London, 179-199. 
North, D. C., 1990. Institutions, Institutional Change, and Economic Performance. Cambridge University Press, Cambridge.

North, D. C., Thomas, R. P., 1973. The Rise of the Western World: A New Economic History. Cambridge University Press, Cambridge.

North, D. C., Weingast, B. R., 1989. Constitutions and commitment: The evolution of institutions governing public choice in seventeenth-century England. The Journal of Economic History 49, 803-832.

Novak, M., 1996. Business as a Calling. Free Press, New York.

Offstein, E. H., Gnyawali, D. R., 2006. A humanistic perspective of firm competitive behavior. Competitiveness Review 16(3/4), 248-261.

Opdebeeck, H., Habisch, A., 2011. Compassion: Chinese and Western perspectives on practical wisdom in management. Journal of Management Development 30(7/8), 778-788.

Ostrom, E., 1986. An agenda for the study of institutions. Public Choice 48(1), 3-25.

Ostrom, E., 1990. Governing the Commons: The Evolution of Institutions for Collective Action. Cambridge University Press, Cambridge.

Parra Guillén, M., Nalda, Á. L., d., Perles, G. S., 2011. Towards a more humanistic understanding of organizational trust. Journal of Management Development 30, $605-614$

Parker, M., 1998. Against ethics. In: Parker, M. (Ed.), Ethics and Organizations. Sage, London, $282-296$. 
Parker, M., 2002. Against Management. Organization in the Age of Managerialism. Polity Press, Cambridge.

Parker, M., Fournier, V., Reedy, P., 2007. The Dictionary of Alternatives: Utopianism and Organization. Zed Books, London.

Pies, I., 1993. Normative Institutionenökonomik. Mohr Siebeck, Tübingen.

Pirson, M., Turnbull, S., 2011. Toward a more humanistic governance model: Network governance structures. Journal of Business Ethics 99, 101-114.

Pirson, M., Kimakowitz, E. v., Dierksmeier, C., Spitzeck, H., Amann, W., 2011. Concluding remarks. In: Kimakowitz, E. v., Pirson, M., Dierksmeier, C., Spitzeck H., Amann, W. (Eds.), Humanistic Management in Practice. Palgrave Macmillan, Basingstoke, $307-324$

Popper, K., 1994. The Poverty of Historicism. Routledge, London.

Raico, R., 1964. The fusionists on liberalism and tradition. New Individualist Review 3(3/Autumn), 29-36.

Reisman, D. A., 1998. Adam Smith on market and state. Journal of Institutional and Theoretical Economics 154, 357-384.

Reisman, D. A., 2015. James Buchanan. Palgrave Macmillan, Basingstoke.

Rocha, H., Miles R., 2009. A model of collaborative entrepreneurship for a more humanistic management. Journal of Business Ethics 88, 445-462.

Rosanas, J. M., 2008. Beyond economic criteria: a humanistic approach to organisational survival. Journal of Business Ethics 78, 447-462. 
Sandelands, L. E., 2015. The business of business is the human person. In: Melé, D., Schlag, M. (Eds.), Humanism in Economics and Business. Springer, London, 165-178.

Santelli, A. J., Sikkenga, J., Sirico, R. A., Yates, S., Zúñiga, G., 2002. The Free Person and the Free Economy: A Personalist View of Market Economics. Lexington, Oxford.

Sen, A., 1990. Rational fools: a critique of the behavioral foundations of economic theory. In: Mansbridge, J. J. (Ed.), Beyond Self-Interest. University of Chicago Press, Chicago, 25-43.

Simon, H. A., 1945. Administrative Behavior. Free Press, New York.

Simon, H. A., 1955. A behavioral model of rational choice. Quarterly Journal of Economics 69, 99-118.

Simon, H. A., 1956. Rational choice and the structure of the environment. Psychological Review 63, 129-138.

Simon, H. A., 1993. Altruism and economics. American Economic Review, Papers and Proceedings 83(2), 156-161.

Smith, A., 1759/1966. Theory of Moral Sentiments. A. M. Kelley, New York.

Smith, A., 1776/1976. An Inquiry into the Nature and Causes of the Wealth of Nations. Ed. by Campbell, R.H., Skinner, A. S., Todd, W. B., 2 Vols. Clarendon Press, Oxford.

Spitzeck, H., 2011. An integrated model of humanistic management. Journal of Business Ethics 99, 51-62. 
Suchanek, A., 1994. Ökonomischer Ansatz und theoretische Integration. Mohr Siebeck, Tübingen.

Swart, J. C., 1973. The worth of humanistic management. Business Horizons 16(3), 41-50.

Taylor, F. W., 1903. Shop Management. Reprinted in: Taylor, F. W. (Ed.), 1964. Scientific Management. Harper and Row, London.

Taylor, F. W., 1911. The Principles of Scientific Management. Reprinted in: Taylor, F. W. (Ed.), 1964. Scientific Management. Harper and Row, London.

Taylor, F. W., 1912. Taylors Testimony before the Special House Committee. Reprinted in: Taylor, F. W. (Ed.), 1964. Scientific Management. Harper and Row, London.

Vanberg, V. J., 1992. A constitutional economics perspective on international trade. OrdoJahrbuch für die Ordnung von Wirtschaft und Gesellschaft 43, 375-392.

Vanberg, V. J., 2001. The Constitution of Markets. Essays in Political Economy. Routledge, London.

Vanberg, V. J., 2014. James M. Buchanan's contractarianism and modern liberalism. Constitutional Political Economy 25, 18-38.

Vermander, B., 2011. Chinese wisdom, management practices and the humanities. Journal of Management Development 30, 697-708.

Viner, J., 1927. Adam Smith and laissez faire. Journal of Political Economy 35(2), 198-232.

Vogel, D., 1991. The ethical roots of business ethics. Business Ethics Quarterly 1(1), 101-120. 
Wagner-Tsukamoto, S. A., 2003. Human Nature and Organization Theory: On the Economic Approach to Institutional Organization. Edward Elgar, Cheltenham.

Wagner-Tsukamoto, S. A., 2005. An economic approach to business ethics: Moral agency of the firm and the enabling and constraining effects of economic institutions and interactions in a market economy. Journal of Business Ethics 60, 75-89.

Wagner-Tsukamoto, S. A., 2007a. Moral agency, profits and the firm: Economic revisions to the Friedman theorem. Journal of Business Ethics 70, 209-220.

Wagner-Tsukamoto, S. A., 2007b. An institutional economic reconstruction of Scientific Management: On the lost theoretical logic of Taylorism. Academy of Management Review 32, 105-117.

Wagner-Tsukamoto, S. A., 2008a. Scientific Management revisited: Did Taylorism fail because of a too positive image of human nature? Journal of Management History $14,348-372$.

Wagner-Tsukamoto, S. A., 2008b. Contrasting the behavioural business ethics approach and the institutional economic approach to business ethics: insights from the study of Quaker employers. Journal of Business Ethics 82, 835-850.

Wagner-Tsukamoto, S. A., 2009. Is God an Economist? An Institutional Economic Reconstruction of the Old Testament. Palgrave Macmillan, Basingstoke.

Wagner-Tsukamoto, S. A., 2010. Out of a slave contract: The analysis of pre-Hobbesian anarchists in the Old Testament. Constitutional Political Economy 21, 288-307. 
Wagner-Tsukamoto, S. A., 2012. Updating Adam Smith on business ethics: institutional economics and ethical capitalism. Conference Paper, $4^{\text {th }}$ World Business Ethics Forum, 16-18 December 2012. Hong Kong Baptist University, Hong Kong. Leicester Research Archive (LRA): http://hdl.handle.net/ 2381/27650

Wagner-Tsukamoto, S. A., 2013a. Economic humanism and Western management: theory and practice. In: Khan, S. and Amann, W. (Eds.), World Humanism. Cross-cultural Perspectives on Ethical Practices in Organizations. Palgrave Macmillan, Basingstoke, 15-29.

Wagner-Tsukamoto, S. A., 2013b. The Adam Smith problem revisited: a methodological resolution. Journal des Economistes et des Etudes Humaines 19, 63-99.

Wray-Bliss, E., Parker, M., 1998. Marxism, capitalism and ethics. In: Parker, M. (Ed.), Ethics and Organizations. Sage, London, 30-52.

Williams, T. D., Bengtsson, J. O., 2016. Personalism. In: Zalta, E. N. (Ed.), The Stanford Encyclopedia of Philosophy. Summer 2016 web-edition, https://plato.stanford.edu/archives/sum2016/entries/personalism.

Williamson, O. E., 1967. The Economics of Discretionary Behavior. Managerial Objectives in a Theory of the Firm. Kershaw, London.

Williamson, O. E., 1975. Markets and Hierarchies. Analysis and Antitrust Implications. Free Press, New York.

Williamson, O. E., 1985. The Economic Institutions of Capitalism. Free Press, New York. 
Wishloff, J., 2009. The land of realism and the shipwreck of idea-ism: Thomas Aquinas and Milton Friedman on the social responsibilities of business. Journal of Business Ethics 85, 137-155.

Yandell, K. E., 1998. Personalism. In: E. Craig (Ed.), Routledge Encyclopedia of Philosophy. Routledge, London, 315-318. 